sood plates prepared from working drawings supplied by makers, but in many cases the figures indicating dimensions are, unfortunately, so small as scarcely to be legible.

\section{An Elementary Class-book of Practical Coal-mining.}

By T. H. Cockin. Pp. xii +428 . (London: Crosby Lockwood and Son, rgo4.) Price $4 s, 6 d$. net.

IN general character this useful volume resembles the text-books already available for students of coalmining. The work is, however, carried to a rather more advanced stage than has hitherto been considered necessary for an elementary class-book, and chapters are given dealing with allied subjects, such as chemistry, mechanics, the steam-engine, and electricity. The order of treatment differs from that usually adopted, the subjects dealt with being:(I) geology; (2) structure of stratified rocks; (3) coal and coalneids; (4) search for coal; (5) sinking; (6) opening out; (7) miners' tools; (8) explosives; (9) methods of work; (I0) working by long wall; (II) methods of working by pillar and stall; (I2) special methods of work; (13) timbering; (14) coal cutting by machinery; (15) mechanics; (16) steam; (I7) gases; (18) ventilation; (I9) instruments; (20) lighting; (2x) winding; (22) haulage; (23) pumping; (24) surface arrangements; $(25)$ coke making; (26) accidents; and (27) electricity. This arrangement is not so logical ds that adopted by the late Sir C. Le Neve Foster in his elementary work. For example, sinking with rockdrills is described before mining tools, coal-cutting machinery before the elements of mechanics, and electric signals before electric terms are defined. The brief chapter on coke making is hardly necessary, as this subject is usually dealt with in metallurgical treatises. It is doubtful, too, whether the chapters on chemistry, mechanics, steam, and electricity are sufficiently full to give an insight into the allied subjects, for the study of which excellent text-books are available. The illustrations are clear and diagrammatic, and possess the advantage of having been specially drawn for the book.

Bird Notes from the Nile. By Lady William Cecil. Pp. xii $+\mathrm{I}_{3}$; illustrated. (London: Archibald Constable and Co., Ltd., 1904.) Price 2s. $6 d$. net.

THREE claims to high commendation present themselves on the first glance at this elegant little popular work. In the first place, the numerous illustrations are simply exquisite; secondly, technical names are banished from the text; and, thirdly, in the long list of species forming the appendix such names appear to be correctly spelt, and are thoroughly up to date, even to the adoption of the so-called "Scomber scomber" system of alliteration. In her preface Lady William confesses that the notes were written originally solely for her children, who doubtless were desirous of possessing a memento of their parents' Nile trip, but that friends persuaded her to offer them to the public. The adoption of this advice is, in our opinion, fully justified, and while the book has no doubt been found delightful by the young people of the family, it can scarcely fail to be a pleasant companion to the many bird-lovers who make a winter excursion up the Nile. Although no attempt (and very properly) is made at technical descriptions of the various species encountered during the voyage, such notes as are given are in most cases sufficient to render identification an easy matter, to say nothing of the instances when this is rendered self-evident by the illustrations.

No. 1833 , vOL. $7 \mathrm{I}]$

\section{LETTERS TO THE EDITOR.}

[The Editor does not hold himself responsible for opinions expressed by his correspondents. Neither can he undertake to return. or to correspond with the writers of, rejected manuscripts intended for this or any other part of NATURE. No notice is taken of anonymous communications.]

Education and National Efficiency in Japan.

THE notice of my book " Dai Nippon, the Britain of the East," which appeared in NATURE of December I, directed attention to a nation from which much may be learnt at the present time, and it may interest your readers if 1 supplement your article by a few notes from my personal experience and observation. In the memorandum issued by Sir Norman Lockyer suggesting the formation of a British Science Guild, it is stated that the people of this country do not manifest that interest in and belief in the power of science which are noticeable among the peoples of the Continent or of America, and that, in spite of the efforts of many years, the scientific spirit essential to all true progress is still too rare, and, indeed, is often sadly lacking in some of those who are responsible for the proper conduct of many of the nation's activities. The British Science Guild has been proposed with the view of attempting to remedy this evil, and to bring home to all classes the necessity of applying scientific treatment to affairs of all kinds.

The objects of such a guild have been attained, to a very remarkable degree, in Japan, not so much by the formation of a special organisation for the purpose, as by the awakening of the national consciousness to the necessity of keeping in mind certain definite aims, and by the earnest cooperation of the various departments of Government, of scientific associations, and of private organisations of many different kinds. There is, indeed, a danger at the present time in this country of too much importance being attached to mere organisation and machinery, and too little to the spirit which pervades them. Mr. Matthew Arnold, in one of his last official reports on elementary schools, pointed out that " our existing popular school was far too little formative and humanising, and that much of it to which administrators point as valuable results is in truth mere machinery." This applies with far greater force to a great deal which has been done in recent years in the way of scientific and technical education. Instruction and knowledge are too often confounded with education, and mere machinery and organisation prevent the development of the scientific spirit. Many of the men who are supposed to have had a complete technical education are very poor specimens of humanity, wanting in individuality and character, devoid of all originality, and with a very narrow view of the world. Some of them may manage to pile up fortunes for themselves, but they will do little to make their country great. Even from a practical point of view, success in any trade or profession does not depend so much on the amount of information which may have been crammed into the learners' heads as is often supposed. It depends incomparably more upon their capacity for useful action than upon their acquirements in knowledge. All experience proves that the spiritual is the parent and first cause of the practical, and especially the economic history of the Middle Ages shows us that an ounce of manly pride and enthusiasm is worth more than a pound of technical skill.

The recent history of Japan has emphasised this fact While attention has been paid to details, the spirit which has animated the leaders of public opinion and action has been the chief cause of the great developments which have taken place. The complete study of this aspect of Japanese national life would take us into many interesting psychological discussions, but it is sufficient for our present purpose to note that the Japanese mind, unlike the British (which is strongly individualistic), is dominated to a very great extent by collective opinion. At the same time, while Japanese philosophy and their former social order were essentially communistic in their nature, still (contradictory as it may seem) their genius is individualistic, and they impress their personal qualities on their work, although they are willing to sacrifice results to a rigid organisation. The outcome of it all is that the national consciousness is 